Neera Chopra

\title{
E-governance in Higher Education Institutions in India: Status and Prospects
}

\author{
E-közigazgatás az indiai felsőoktatási \\ intézményekben: helyzet és kilátások
}

The demand for higher education has been steadily rising all over the world including developing nations like India. As higher education systems are rapidly expanding, the administration and management of HEIs (Higher Educational Institutions, that is, universities and institutes offering Bachelor, Masters and Doctoral level education) are becoming a complex task. HEIs are now much more diversified in types of institutions, modes of delivery and backgrounds of students. Technology can help HEIs innovate and serve the diversified student body by providing accessible and flexible education experiences. Information and Communication Technology (ICT) also offers unprecedented opportunities for a seamless sharing of knowledge and information between university administrators, teachers, students and all stakeholders.

The main objective of this study is to examine and compare the status of the use of ICT between different types of universities within India. It will further look into the challenges faced by these institutions to implement digital technologies. Besides academic literature, the present study draws upon my previous article on the use of ICT in higher education institutions in India. The study indicates that while ICT is widely used for academic purposes, its use is only limited in the management and administration of higher education. Further studies are needed to identify and suggest means to mitigate the challenges faced by the Indian HEIs towards extensive adoption of ICT. This research will involve conducting, analysing and comparing the results of the in-depth interviews with the administrative heads of concerned institutions. Assessment will also be done through a questionnaire on the integration of ICT in achieving the mission and vision of the HEIs in both private and public universities. The expected results are that private institutions have embarked on technology with greater success and benefits. The study will then recommend steps to profitably use available technologies to improve performance, to enhance the quality of their students and to facilitate all stakeholders. The outcome of the research will provide 
insight into the institutions themselves and the policymakers in the field of education in India on the critical success factors of ICT governance and define a course to develop technology-enabled smart universities.

Keywords: private universities, public universities, university administration, India

A felsőoktatás iránti kereslet folyamatosan növekszik az egész világon, beleértve az olyan fejlődö országokat is, mint India. Mivel a felsőoktatási rendszerek gyorsan bővülnek, a felsőoktatási intézmények (felsőoktatási intézmények, azaz egyetemek és alap-, mester- és doktori szintü oktatást kínáló intézmények) adminisztrációja és irányitása összetett feladattá válik. A felsőoktatási intézmények ma már sokkal szerteágazóbbak az intézménytípusokban, a teljesités módjában és a hallgatók hátterében. A technológia hozzáférhető és rugalmas oktatási tapasztalatokkal segítheti a felsőoktatási intézményeket az innovációban és a sokszinü hallgatói kör kiszolgálásában. Az információs és kommunikációs technológia (IKT) szintén soha nem látott lehetőségeket kinál az ismeretek és információk zökkenömentes megosztására az egyetemi adminisztrátorok, oktatók, hallgatók és minden érdekelt fél között.

A tanulmány fö célja az IKT használatának, állapotának vizsgálata és összehasonlítása Indiában az egyetemek különböző típusai között. A továbbiakban megvizsgálja az ezen intézmények elött álló kihívásokat a digitális technológiák bevezetése terén. Az akadémiai irodalom mellett jelen tanulmány az IKT-nak az indiai felsőoktatási intézményekben történö felhasználásáról szóló korábbi cikkemre támaszkodik. A tanulmány azt jelzi, hogy bár az IKT-t széles körben használják tudományos célokra, a felsőoktatás irányitásában és igazgatásában csak korlátozottan alkalmazzák. További vizsgálatokra van szükség az indiai felsőoktatási intézmények elött álló kihívások enyhitésének és az IKT széles körü elterjesztése felé történő megoldásának megkeresésére. Ez a kutatás magában foglalja az érintett intézmények adminisztrativ vezetőivel folytatott mélyinterjúk lefolytatását, elemzését és összehasonlitását. Az értékelést egy kérdōiv segítségével is elvégzik az IKT integrációjáról a felsőoktatási intézmények küldetésének és jövőképének megvalósitásához a magánés az állami egyetemeken egyaránt. A várt eredmény az, hogy a magánintézmények nagyobb sikerrel és elönyökkel kezdték el a technológiát. A tanulmány ezt követően lépéseket fog javasolni a rendelkezésre álló technológiákjövedelmező felhasználására a teljesitmény javitása, a hallgatók minőségének javitása és az összes érintett helyzetének megkönnyítése érdekében. A kutatás eredménye betekintést nyújt maguknak az intézményeknek és az indiai oktatási politika döntéshozóinak az IKT-irányítás kritikus sikertényezôire, és meghatározza a technológiát támogató intelligens egyetemek fejlesztésének irányát.

Kulcsszavak: magánegyetemek, állami egyetemek, egyetemi adminisztráció, India 


\section{Introduction}

The higher education in India has had a rapid expansion matching with the population growth. Today, a mammoth 39.4 million students are enrolled in the Indian higher education system. It is now the second ${ }^{1}$ largest in the world with around 962 Universities, 38,179 colleges and 9,190 stand-alone institutions. ${ }^{2}$ The growth momentum mainly picked up post-liberalisation during the 1990s. The demand of the market forces led to the proliferation of the private and technical institutions to cater to the surge in enrolment. From the earlier notion of higher education, which was meant only for the elite, researchers have referred to this shift of higher education reaching the masses as the massification of higher education. The massification or the rapid expansion of enrolments is the result of a growing overall population combined with the demand for access. India, being a developing country has not been able to accompany the expansion with matching improvement in quality. ${ }^{3}$ Moreover, it has been advocated that only a few islands of excellence exist in a sea of mediocrity of Indian Universities. ${ }^{4}$ For example, the Indian Institute of Technologies (IITs) have garnered world recognition and no other university figures in the world-class universities list. Perhaps this is the reason that India is the largest exporter of students to foreign universities. Also, the fact that Indian universities do not figure among the top universities has become a cause of intense public debate. ${ }^{5}$

In this scenario, in what ways can the Indian HEIs which cater to the masses, improve in quality, as state finances are also being pulled away owing to resource crunch. ${ }^{6}$ On the one hand, just like the Chinese model, the State has decided to select a few 'Institutes of Eminence' and fund them adequately; but on the other hand, India still cannot deviate from the aim of growth in enrolment at the cost of a higher aim of quality to figure in world-class universities. As Selwyn has argued, higher education is facing increasing financial accountability and pressure to perform efficiently and profitability. ${ }^{7}$ The UGC (regulatory body on higher education) stresses the need to bring efficiency in Indian higher educational institutions through the use of technology (UGC handbook for Vice-chancellors). It has advocated e-governance in the administration and management in HEIs to improve and ease its institutional challenges. The issue here is to frame reforms by introducing e-governance in higher education institutes to such a way that institutional autonomy, initiative and diversity is preserved; and that wasteful competition and duplication is avoided. Amidst this background, this paper is divided into eight sections. After the literature review and listing the objectives, the fourth section will

India has surpassed the USA in enrolments and is now the second largest after China, which has 40 million enrolments in tertiary education.

AISHE Final Report 2018-2019.

Martin Carnoy and Rafiq Dossani, The Changing Governance of Higher Education in India (Working Paper, Stanford University, 2011).

Pawan Agarwal, Indian Higher Education: Envisioning the Future (New Delhi: Sage Publications, 2009). Jagadesh M Kumar, 'Global University Rankings: What should India do?' IETE Technical Review 32, no 2 (2015), 81-83.

6 Garima Malik, Governance and Management of Higher Education Institutions in India (New Delhi: NUEPA, 2017).

Neil Selwyn, 'The use of computer technology in university teaching and learning: a critical perspective', Journal of Computer Assisted Learning 23, no 2 (2007), 83-94.

Európai Tükör 2020/4. 
briefly touch upon the current scenario of higher education, its structure and emerging trends. In the fifth section the term e-governance and its stages are explained. Also, it will apprise the initiatives taken by the Ministry of Education to introduce ICT based change in Indian higher education and later the need for e-governance in universities. The next section will examine the status of ICT in the select universities of different types. The last chapter will discuss the findings and recommendations.

\section{Literature review}

The modernisation of the educational sector is imperative in the $21^{\text {st }}$ century to keep pace with the digital economy and society. However, there are indications that the Indian higher education is yet to fully integrate the benefits of technology as compared with the revolution of ICT in other sectors. Most of the HEIs are slow in adapting integration of ICT and do not leverage e-governance up to the mark to address the demand of the stakeholders. ${ }^{8}$ Moreover, the literature reveals that research in varying magnitude has been undertaken as to how technology is used to educate, the effectiveness of online teaching and the growing use of digital technology in the classroom; yet, very scant attention is paid to the background phenomenon in education such as the management and governance in HEIs. ${ }^{9}$ Also, the ICT applications in organisational and management are fragmented and less systematic; more like silos than a unified whole. To cite an example, Enterprise Resource Planning (ERP: the generic term for software solution package) is best effective if implemented organisation-wide. In the absence of a complete ERP solution in maintaining the complete life cycle of a student, for instance, the information needed in each department calls for duplication of efforts. Researchers Al-Adawi et al. (2005) show that e-governance is surrounded by political, economic, cultural, technological and institutional factors, which significantly influence the numerous stages of e-governance implementation. This article will evaluate these factors in the implementation of e-governance in the university system of India. Apart from new modes of teaching and learning through ICT, the deployment of ICT in administration and management of HEIs have also resulted in unprecedented opportunities for a seamless sharing of knowledge and information between university administrators, teachers, students and all stakeholders. Thus, the evaluation of the performance of universities in the field of ICT is a necessity.

\section{Objectives of the study}

Technology is all-pervasive and has invaded all facets of human life, the higher education sector being no exception. At the same time, it is observed that the penetration of

\footnotetext{
$8 \quad$ Ekambaram Ramganesh, Ezra Kirubakaran and R Gobi, 'A Roadmap for a Higher Learning Institution-based M-governance Framework in the Grey Revolution', International Journal of Advanced Research in Computer Science and Software Engineering 5, no 8 (2015), 152-155.

9 Jill Jameson, 'E-Leadership in higher education: The fifth "age" of educational technology research', British Journal of Educational Technology 44, no 6 (2013), 889-915.
} 
technology, particularly information technology in the higher education sector has not been as extensive as in other sectors. ${ }^{10}$ The objectives of this study are two-fold:

1) to examine the challenges faced by Higher Educational Institutions while implementing digital technologies

2) to examine and compare the status of the use of ICT in different types of universities in India

\section{The structure of Indian universities}

The first universities in India were established in 1857 on the western model based on the London University by the Colonial rulers. ${ }^{11} \mathrm{~A}$ university is created by a charter given to it either by the union or the state legislature and is expected to work as an autonomous organisation. Both central and state universities are public universities funded by the government with no profit motive and are bounded by rules and regulations of the government through the regulatory body UGC. ${ }^{12}$ Till the late 1980s, higher education was funded by the government owing to its public nature, ${ }^{13}$ as knowledge was for all and should be available to the public at a nominal cost. The scenario today is changing with reduced funding by the state and the traditional public universities transforming from free for all courses to self-finance courses to mobilise resources. In the 1990s, with the rising demand from the middle-class ready to fund education, private educational institutions entered the higher education arena. ${ }^{14}$ In terms of number, private universities which are formed under the State Private University Act have grown phenomenally from a meagre 42 in 2009 to 282 in $2018 .{ }^{15}$ Unlike public universities, private universities charge high tuition fees and have limited control by the state. Another type of university in India mushroomed in the twenty-first century which is termed as deemed university. It is formed by the MoE on the recommendations of the UGC. They also enjoy autonomy in respect of fees and run market-driven courses rather than conventional ones. These universities manage well with good ICT infrastructure and update the curriculum with changing demands. Then there are open universities and institutes of national importance which are also public universities and are funded by the government. It is observed that from the traditional three university types there were 19 universities in 1947 (when India gained independence) and which have now grown to $945 .{ }^{16}$ Given India's

\footnotetext{
10 Ron Oliver, 'The role of ICT in higher education for the $21^{\text {st }}$ century: ICT as a change agent for education', January 2002.

11 Mona Sedwal, 'The Emergence and Expansion of Indian Universities Before Independence: A Historical Perspective', in The Future of Higher Education in India, ed. by Sudhanshu Bhushan (Singapore: Springer, 2019), 23.

12 UGC is the regulatory body which coordinates the determination and maintenance of standards in teaching, examination and research of higher education in India.

13 In the words of Samuelson, public good is one where the consumption by one individual does not diminish the consumption of another individual (Paul A Samuelson, 'The Pure Theory of Public Expenditure', The Review of Economics and Statistics 36, no 4 (1954), 387).

14 Sudhanshu Bhushan (ed.), The Future of Higher Education in India (Singapore: Springer, 2019).

15 UGC: 'Annual Report 2018-2019'.

16 Ibid.
} 
demographic and socioeconomic conditions, the growth in enrolment is quite impressive; nevertheless, the problem is that the existing capacity to absorb the increasing numbers of students into the college system is not compensated by matching funding. ${ }^{17}$ Also, the inadequate number of public HEIs causes a massive mismatch between demand and supply frontiers. ${ }^{18}$

Universities in India are ostensibly, autonomous bodies, with the state expected to play a supervisory role. However, the reality is different with an almost complete financial and often as a result, administrative dependence in case of all the central and state universities. Control is exerted, beginning with the appointment of vice-chancellor to these institutions by the government. The state thus maintains a tight vigil over their spending, granting of degrees, compensation to faculty, curriculum, and so on. Besides, there are frequent approvals mandated by the central or the state government officials in the form of various committees constituted for this purpose.

There have been various committees and reports ${ }^{19}$ on higher education which have put across ways and means to provide greater autonomy and decentralise authority. As pointed out by the OECD in 2005, autonomy is usually determined by the capability and right of an institution to decide its course of action pertaining to institutional policy, planning, financial and staff management, compensation and academic freedom without interference from outside authorities. However, of late the control mechanisms have assumed different forms from previous regulation and exert a more intensive and stronger influence through performance-based accountability, quality assurance, accreditation and rankings. The focus now is on managerialism in universities. Management is action-oriented and is concerned with the efficiency, effectiveness and quality of services provided to internal and external stakeholders. The institutions now need to show that the funds that they are receiving are being used responsibly; and they need to maintain standards in excellence in teaching and research. ${ }^{20}$ To sum up, institutions need to strengthen their capacity and become competitive in performance.

\subsection{Funding}

Higher education institutions are also like organisations that aim at better delivery of their services. On the one side, there has been a spurt in the growth of enrolment in the

17 R P Saxena, 'Governance of Indian Universities: From Decay to Dynamism?' Higher Education 20, no 1 (1990), 91-111.

18 K K Jahan and D C Selvarani, 'Higher Education in India: Issues and Challenges', International Conference on Humanities, Literature and Management (ICHLM'15) January 9-10, Dubai (UAE), 2015, 81-86.

19 The University Education Commission (1948-1949, p. 42), the first university commission, recommended that universities should be released from the control of politics as the 'intellectual progress demands the maintenance of the spirit of free enquiry'. The Kothari Commission Report (1864-1866, pp. 650-654) also mentions that the universities have to continually earn and deserve their autonomy by discharging their intellectual and public obligations effectively and also universities should be immune to direct government intervention and also from direct public accountability in financing. 
HEIs in India and on the other side, according to various studies on the funding patterns of higher education, the governments are decreasing the public funding. As stated in the introduction, the rapid expansion and massification are placing a fiscal burden on the state, leading to the withdrawal of the state funding. ${ }^{21}$ 'The central and state Governments jointly fund higher education. The central government's share is about 30 per cent while the state government's share is 70 per cent mostly under the non-plan head. Overall, the central funding of state institutions is meagre. ${ }^{22}$ State universities and colleges face serious financial difficulties that often result in poor quality.

The expenditure on higher education as a percentage of GDP in 1990-1991 was 0.43 per cent which in the year 2009-2010 declined to 0.41 per cent. ${ }^{23}$ In addition to the lack of sufficient funds, it is also observed that there is a gap between funds allocated and utilisation of funds. Hence, the allocation is delayed as the universities fail to send the utilisation in the prescribed format, mandatory for further release of the allocated amount. To overcome the resource crunch, universities are being encouraged to mobilise resources on their own, become more entrepreneurial and managerial in approach. ${ }^{24}$ The regulating bodies of higher education have also recommended stimulating industry investment and introducing ICT initiatives in the administration and management of HEIs for smooth functioning.

\subsection{The issue of affiliation}

There are 268 affiliating universities ${ }^{25}$ across India and over 39,000 colleges between them. The colleges affiliated to the university have to conform to the university syllabus and examinations schedule of the concerned university. The degrees awarded by the colleges are of the affiliating university. Out of these 268 universities, seventeen have more than 500 colleges affiliated to them. The active resources of the university are diverted towards the conduct of exams for these affiliated colleges with the consequent dilution of focus on academic quality and research. E-governance can help in automating the whole examination process, thereby reducing the pressure on universities in monitoring the affiliated colleges.

It is now observed that the new progressive Indian higher education institutions have a substantial advantage over public institutions in developing compatible student affairs structures, providing market-driven employable courses and many new subjects

\footnotetext{
21 Malik, Governance.

22 Saxena, 'Governance of Indian Universities'.

23 Anuneeta Mitra, 'Public Spending in Higher Education in India: A Benefit Incidence Analysis', Higher Education for the Future 2, no 1 (2015), 71-91.

24 GoI, Annual Report 2005-2006 of the Ministry of Personnel, Public Grievances and Pensions (New Delhi: Government of India, 2006).

25 Generally, they have a central campus on which departments or schools or institutes are located that impart postgraduate centres located outside the campus in different districts. Affiliating universities may also have university colleges (within the campus) as well as constituent colleges (outside the campus). These universities have a variable number of colleges affiliated to them. The affiliating practice, which links the colleges and the university, has long been given up in the country of its origin and it does not exist anywhere in the world except India, Pakistan and Bangladesh.
}

Európai Tükör 2020/4. 
that had hardly any existence in the earlier public universities. The private universities are more competitive to attract students who are not learning to acquire knowledge but for the job oriented market-driven subjects. ${ }^{26}$ With the state directing public universities to mobilise resources and start 'self-finance courses' to augment resources, public universities have to adapt to the new demands of the society. They even have to change the teaching-learning process with technology as the effective integration of ICT plays a critical role in maintaining a university competitive. ${ }^{27}$

Additionally, universities must have ICT incorporated in daily activities, especially because students today (digital natives) ${ }^{28}$ possess advanced knowledge and skills in ICT and are highly motivated to learn in this mode. The best use of ICT can be to bring the focus on student-centred learning. The administrative heads of the HEIs also acknowledge this fact and are in the process of boosting the use of technology in the institutions.

To sum up, the current scenario of Indian higher education includes a good share of the private sector apart from traditional public universities. Nevertheless, the policy shift has led to encouraging performance-based resource allocation, fostering inter-institutional competition, efficient management and administration through technology.

\section{E-governance in India}

Over the past decade, ICTs have revolutionised our lives profoundly. ICT tools have rapidly evolved and have now reached the masses through the ubiquity of smartphones. In India, more than half of the population is now connected to the internet and their smartphones. This penetration of ICT tools is an important milestone for e-services to be offered by the government to the people. These e-services also become personalised depending upon the needs and intent of the individual. With the use of ICT, there has been a paradigm shift in governance. Governance is now more efficient, effective and transparent through the ICT applications. More and more services are being offered online through interactive websites and portals easing the citizen's interaction with the government. E-governance can achieve many functions providing information and improving the internal efficiency through the use of automation and digital technologies, acting as a channel between the public officials and citizens and offering improved interactions with the external stakeholders like businesses and other public departments. ${ }^{29}$ E-governance is defined as the use of ICT to improve information and service delivery, encouraging citizen participation in the decision-making process and making government more accountable, transparent and effective. Thus, e-governance is in essence, the

Bhushan, The Future of Higher Education in India.

Stensaker, Bjorn et al., 'Use, updating and integration of ICT in higher education: Linking purpose, people and pedagogy', Higher Education 54, no 3 (2007), 417-433; Wang, Xi et al., 'Optimal professional development ICT training initiatives at flagship universities'. Education and Information Technologies 25 (2020), 4397-4416.

28 Term given by Marc Prensky, 'Digital Natives, Digital Immigrants', On the Horizon 9, no 5 (2001), 1-6.

29 Shailendra C Palvia and Sushil S Sharma, 'E-government and e-governance: Definitions/domain framework and status around the world', in Foundations of E-government, ed. by Ashok Agarwal and V Venkata Ramana (ICEG 2007), 1-12. 
application of Information and Communications Technology to government functioning to create 'Simple, Moral, Accountable, Responsive and Transparent' (SMART) governance. ${ }^{30}$ The researches over the years reveal the advantages of e-government to the conventional, traditional bureaucratic structures because it includes faster dissemination of administrative information and provide for instant and efficient transactions. Thus, given the limited public economic resources in recent years, ICT improves productivity and efficiency while at the same time reducing the transaction costs.

\subsection{Stages of e-governance}

The far-reaching benefits of web-technology have encouraged organisations and public departments to establish an online presence and publish information on websites. The websites contain up-to-date information, policies, databases, laws and other relevant information and regulations. There has been significant research on how e-governance evolves through the stages. For example, the stage model proposed by Gartner; the evolution of e-government has four stages. The first stage is presence creating a virtual environment on the internet to provide the public with access to information. The second stage is interaction which allows accessing forms and other links. The third is the transaction stage which allows users to execute online services like obtaining a license and making payment. Finally, the transformation stage which provides integration of regional and national websites and provides full communication with all government offices and non-governmental organisations. Each of these stages of evolution has a distinct focus. In the initial stages of the rise of e-governance, the focus is on the technology aspect or IT related and issues related to information management. The second phase begins with the web 2.0 facilitating access to information and interaction between public departments and citizens through the websites. In the third phase security issues, accountability, reliability legislations, participation tools and organisations arise.

At a macro level, the stage of evolution of e-governance is dependent upon the degree of development. The more developed a nation, the greater its chances of achieving a higher stage of evolution. The liberalisation of the economy in 1990 and the resultant economic growth saw rapid inception of e-governance, which proceeded through four stages in India viz. computerisation in the 1970s, networking within organisation in 1990s, online presence with increasing internet connectivity and then in the current stage online interactivity and delivery of public services to citizens.

According to the UN E-Government Survey 2020, European countries like Denmark, Estonia and Finland are among the highest-ranked nations in e-government index. The position of India is 100 this year, whereas Hungary stood at 52 out of the total list of 196, ahead of many other Eastern European nations. Nevertheless, on disaggregating the EGDI index 2020, it is found that India fares very well in the online service provision index. India has achieved a score of 0.871 which compares rather well with the

30 Saxena, 'Governance of Indian Universities'.

Európai Tükör 2020/4. 
top countries (Estonia, Denmark Finland, where it is 1.0$) \cdot{ }^{31}$ Despite a delayed provision of infrastructure, digital divide and other resources issues, today India is the leader in Asia in the provision of online services. This suggests that even with limited resources, countries progress in e-government development if they are supported in other ways through visionary leadership and enabling policy frameworks. For example, the government has given a policy directive to each public department to allocate 3 per cent of funds towards computerisation and 8 per cent of funds towards IT infrastructure. It is found that with the launch of the Digital India programme in 2015 to bridge the digital divide, the consequent creation of digital infrastructure and availability of the digital services has led to an expansion in the online services (MEITY website).

Besides, with the advent of smartphones, e-services have reached the masses. New technologies have also changed the entire process and structures of government bodies in processing information and delivering services such as payment of bills, taxes and host of other services. ${ }^{32}$ Recognising the advantages of digital transformation, e-governance is also being adopted by academic institutions to improve its internal functioning and automate service delivery to its varied stakeholders - students, faculty, policymakers, accrediting bodies.

\subsection{The importance of e-governance in higher education}

Technology has been in use in educational institutions for fulfilling its basic objectives. The primary functions of education undoubtedly are teaching and learning, the very reason for its being. Nevertheless, for the smooth functioning of an educational institution, adequate attention needs to be paid to the process of management and governance. These include several functions like conducting examinations, awarding degrees, managing the affiliated colleges, staff administration and student information to name a few. As mentioned in the earlier section, many universities in India have more than 500 colleges under their affiliation prompting academicians to term universities as examination conducting bodies. ${ }^{33}$ This peculiarity of the Indian education system is taking a toll on the real objective; and universities are burdened with conducting examinations around the year for its affiliated colleges with issuing of hall tickets, setting and printing of question papers, arranging time-tables, evaluating answer sheets, declaring results, arranging revaluation and so on. Automation of governance and administration processes would enable a university to better focus on its basic objective.

E-governance is an integrated solution that facilitates the processing and maintenance of large volumes of information, including student, faculty, inventory

31 UN E-Government Survey 2020. Online: https://publicadministration.un.org/egovkb/en-us/Reports/ UN-E-Government-Survey-2020

32 Sunil K Muttoo, Rajan Gupta and Saibal Kumar Pal, E-Governance in India (Singapore: Springer, 2019).

33 Bhushan, The Future of Higher Education in India. 
management, facility management, transport, library, staff details, and payroll and accounts among various departments in an academic institution. ${ }^{34}$

Their study also revealed that each institution must work within the context of its system to fit choices to what best suits its unique situation and culture. The advancement of technology and the way it was incorporated into a system was a dynamic process. Even within one institution, various units or courses might use different approaches. The possible areas of implementation of e-governance in the educational sector are:

E-administration: It involves the use of information and communication technology (ICT) to improve administration processes and the internal working of the departments within an educational organisation.

E-services: The main aim is to improve the delivery of services to students by providing services online. Some examples of interactive services are requests for documents, certificates, reading material, admit cards and identity cards.

E-participation: It promotes greater student, faculty and other stakeholder participation enabled by ICTs in the decision-making process.

The introduction of e-governance entails streamlining operational processes, transcribing information held by government agencies into electronic form, linking disparate databases, and improving ease of access to services for members of the public. The advantages of ICT over conventional systems include greater accessibility, wider multi-communication and faster dissemination of information. Use of ICT in governance can make governments and organisations more efficient and effective. Moreover, its automatic record-keeping features generally enable better knowledge management and information sharing.

The benefits associated with ICT tools have led to the development of individual ERP modules in various processes of the HEIs. According to the UGC Handbook for Vice-Chancellors 2019, some of the core modules are related to:

1) Academic Processing system

2) Finance, Accounts, Purchase and Inventory

3) Payroll and Human Resource Management systems

4) Assets Management

5) Examinations, Evaluation and Results processing

The universities can conceive and concretise the e-government software programs and run these programmes in the universities to speed the internal functioning as well as provide user-friendly access to outsiders. E-governance will enable smooth flow of information, requests, reporting between the university administration and its varied stakeholders such as students, staff, faculty, board members and accrediting bodies.

R Krishnaveni and J Meenakumari, 'Usage of ICT for Information Administration in Higher Education Institutions - A Study', International Journal of Environmental Science and Development 1, no 3 (2010), 282-286. 


\subsection{Initiatives by the $M o E$}

Noting that ICT plays a vital role in the global progress, and also that India has a respectable presence in the ICT development sector, the Ministry of Education (MoE), a policy-making body on higher education in India is ushering in ways and means to incorporate ICT in the daily activities of the Indian HEIs. Various reforms have been introduced by MoE, including a common e-governance module 'e-Samarth' to smoothen the background processes in HEIs. Samarth is an open-source, scalable ERP (Enterprise Resource Planning; the generic term for software solution package) system to replace the legacy system of administration and management in HEIs. The National Programme for Technology Enhanced Learning (NPTEL) launched in 2001 is another initiative of MoE which promotes education through technology. The Mission has planned a variety of initiatives aimed at developing and standardising digital content for the Indian higher education segment. The Mission envisions catering to the learning needs of 500 million people in the country. ${ }^{35}$ Another dynamic beginning by the MoE is the indigenous Swayam platform for hosting MOOCs in higher education which is free and accessible to all. Under this initiative, the university students who complete the course can also obtain credits for up to 20 per cent in their respective degree programs (MHRD digital initiatives booklet 2019).

\section{Research methodology}

Creswell defines qualitative research thus: 'Qualitative research is an approach for exploring and understanding ascribed to a social or human problem. The process of research involves emerging questions and procedures, data typically collected in the participant's setting, data analysis inductively building from particulars to general themes, and the researcher making interpretations of the meaning of the data' meaning by qualitative research, the study is context-bound and time-specific. This is the appropriate method since e-governance in HEIs cannot be studied outside the actual context. This study relies on both secondary as well as primary data sources. Secondary data include academic literature relevant to the topic, which is referred to form a theoretical edifice.

Pegu, Uttam K: 'Information and Communication Technology in Higher Education in India: Challenges and Opportunities'. International Journal of Information and Computation Technology, 4 (2014), 513-518. 
Primary research involves conducting, analysing and comparing the results of the in-depth interviews with the administrative heads, ICT in charge, faculty and staff of the selected five institutions. In-depth interviews that used open-ended questions and documents analysis were conducted to collect data related to sociotechnical challenges in the implementation of e-governance. The study applies a comparative methodology and is carried out in the five universities located in different Indian cities/towns. One of these is a central university, the second one is a rural university; one each, a private and an open and the fifth one is an institution of national importance (funded by the central government). To avoid their identification, these universities are coded as A, B, C, D and E respectively. Data has been collected through web-based questionnaires tailored to the decision-makers/support staff in the administration department of the respective universities. Besides the responses to these questionnaires, the assessment includes examining the web sites of these universities to gather secondary data related to the mission statement, the vision and other strategic initiatives. The following parameters, adapted from the research of Stensaker et al. (2007) is used to examine the status of and the challenges faced in the implementation of ICT in different universities:

1. top management involvement and support

2. use of ICT in the strategic planning

3. inclusion of ICT in HR activities

4. internal marketing of ICT in the organization

5. availability of technical support and backup

6. availability of services like on-line registration for admission ${ }^{36}$

\section{Findings and discussion}

The purpose of this study is how the selected HEIs have implemented e-governance; to what extent has the technology been integrated; what are the issues and challenges in the implementation process. Through analysing the data, five main themes as listed above based on the study by Stensaker were examined. This section discusses findings of the present study. These findings are presented in a tabulated form below, followed by a detailed explanation against each of the selected parameters for all the five selected universities. 
Table 1

Findings of the study

\begin{tabular}{|c|c|c|c|c|c|c|}
\hline $\begin{array}{l}\text { Code and } \\
\text { type of } \\
\text { university }\end{array}$ & $\begin{array}{l}\text { Top man- } \\
\text { agement } \\
\text { involve- } \\
\text { ment and } \\
\text { support }\end{array}$ & $\begin{array}{c}\text { ICT in } \\
\text { strategic } \\
\text { planning }\end{array}$ & $\begin{array}{l}\text { Inclusion of } \\
\text { ICT in HR } \\
\text { activities }\end{array}$ & $\begin{array}{c}\text { Internal } \\
\text { marketing } \\
\text { of ICT }\end{array}$ & $\begin{array}{c}\text { Availability } \\
\text { of technical } \\
\text { support and } \\
\text { backup }\end{array}$ & $\begin{array}{c}\text { Availability } \\
\text { of web- } \\
\text { based } \\
\text { services }\end{array}$ \\
\hline $\begin{array}{l}\text { A Public } \\
\text { university }\end{array}$ & $\begin{array}{l}\text { The initiative } \\
\text { from the top } \\
\text { is less }\end{array}$ & $\begin{array}{l}\text { Included in } \\
\text { the strategic } \\
\text { planning }\end{array}$ & $\begin{array}{l}\text { Shifting to } \\
\text { e-govern- } \\
\text { ance model } \\
\text { soon on the } \\
\text { directions of } \\
\text { the MoE }\end{array}$ & $\begin{array}{c}\text { Almost } \\
\text { absent }\end{array}$ & $\begin{array}{l}\text { No dearth } \\
\text { of staff but } \\
\text { implementa- } \\
\text { tion is less }\end{array}$ & $\begin{array}{c}\text { Limited } \\
\text { to online } \\
\text { admission; } \\
\text { transactional } \\
\text { facility not } \\
\text { available } \\
\end{array}$ \\
\hline $\begin{array}{c}\text { B Rural } \\
\text { university }\end{array}$ & $\begin{array}{l}\text { Owing to } \\
\text { the digital } \\
\text { divide, sup- } \\
\text { port is less }\end{array}$ & & $\begin{array}{l}\text { Varied levels } \\
\text { between } \\
\text { different ERP } \\
\text { modules }\end{array}$ & $\begin{array}{c}\text { Almost } \\
\text { absent }\end{array}$ & $\begin{array}{l}\text { Infrastruc- } \\
\text { ture man- } \\
\text { ageable but } \\
\text { unimpressive } \\
\text { IT staff } \\
\end{array}$ & $\begin{array}{l}\text { Limited } \\
\text { services }\end{array}$ \\
\hline $\begin{array}{l}\text { C Private } \\
\text { university }\end{array}$ & $\begin{array}{l}\text { Genuinely } \\
\text { involved }\end{array}$ & $\begin{array}{l}\text { Included in } \\
\text { the strategic } \\
\text { planning }\end{array}$ & Present & $\begin{array}{l}\text { Much atten- } \\
\text { tion is given } \\
\text { to the issue } \\
\text { and consider- } \\
\text { able actions } \\
\text { are taken }\end{array}$ & $\begin{array}{c}\text { Trained } \\
\text { workforce }\end{array}$ & $\begin{array}{l}\text { Human } \\
\text { interface lim- } \\
\text { ited and eff- } \\
\text { cient online } \\
\text { services }\end{array}$ \\
\hline $\begin{array}{c}\text { D Open } \\
\text { university }\end{array}$ & $\begin{array}{l}\text { Institutional } \\
\text { top-man- } \\
\text { agement } \\
\text { involved in } \\
\text { the initiation }\end{array}$ & $\begin{array}{l}\text { Included in } \\
\text { strategic } \\
\text { planning }\end{array}$ & Present & $\begin{array}{l}\text { Necessity } \\
\text { owing to ease } \\
\text { of use }\end{array}$ & $\begin{array}{l}\text { Adequate } \\
\text { measures are } \\
\text { taken }\end{array}$ & $\begin{array}{c}\text { Human } \\
\text { interface lim- } \\
\text { ited and effi- } \\
\text { cient online } \\
\text { services }\end{array}$ \\
\hline $\begin{array}{l}\text { E Institute } \\
\text { of national } \\
\text { importance }\end{array}$ & $\begin{array}{c}\text { Easy to } \\
\text { finance new } \\
\text { technology }\end{array}$ & $\begin{array}{c}\text { Almost } \\
\text { absent }\end{array}$ & $\begin{array}{l}\text { Fragmented } \\
\text { implementa- } \\
\text { tion }\end{array}$ & $\begin{array}{l}\text { Almost } \\
\text { absent }\end{array}$ & $\begin{array}{l}\text { No dearth } \\
\text { of infra- } \\
\text { structure } \\
\text { facilities but } \\
\text { unimpressive } \\
\text { IT staff }\end{array}$ & $\begin{array}{l}\text { Varied levels } \\
\text { between } \\
\text { different ERP } \\
\text { modules }\end{array}$ \\
\hline
\end{tabular}

Source: Compiled by the author.

\subsection{Top management involvement and support}

In private university $(C)$, the leadership gives time-bound targets to achieve digitalisation, unlike centrally funded institutions. Staff are competent, unlike central universities where they are being trained. According to the ICT head in the central university, the trainers are also chosen among the staff and resource persons from those who have received training to boost willingness to adopt technology and promote ease of use.

By and large, there is a low level of involvement and support from the top management in ICT related issues in centrally funded universities. The main reason cited for the implementation of ICT in these universities is the order from the Ministry of Human Resource Development that in a way forces the top and the line management to take necessary action. The situation in private universities is totally in contrast, where the top 
management is genuinely involved and is the driving force behind the implementation and use of ICT. That appears to be the reason behind time-bound targets and achievement and a better-trained workforce.

\subsection{ICT in strategic planning}

While going through the website and the documents available through links provided therein, it is observed that the ICT plan is not a part of the strategic planning in all the universities under study. There is a definite ICT plan in case of universities $C$ (a private university), D (open university) and $\mathrm{E}$ (institution of national importance). However, it was distinct from the strategic planning in each of these cases. For the other two universities, A (government university) and B (rural university) there was no ICT plan displayed, although the university had a functioning digitalisation otherwise.

As per normative assumptions, ICT plan must be a part of the larger strategic plan of the university. ${ }^{37}$ However, the findings suggest that even where a distinct ICT plan was there, it was independent of the strategic planning. That is not the ideal position for the integration of the progress on ICT with overall development in the university. Such a linkage would ensure better and time-bound implementation of ICT with the availability of funds.

\subsection{Inclusion of ICT in HR activities}

HR modules for leave management are present and functional in university A, but not in any other university including the private university. In university A, in fact, in addition to the HRM module, the finance module is automated. No application on paper is accepted for HR and finance functions. A more specific comment from the ICT in charge of university A on the technology initiative:

This initiative is done largely for reporting... how many requests are pending and at what stage .... how the leadership is going to use it is not known nor are they taking an interest. Any request generated by faculty and staff on paper on $H R$ functions and finance functions will not be entertained.

The view shared by the institution bought home the point that introduction of automated modules to ease the HR functions was important. Almost all the other government-funded universities commented that they wanted to introduce automation in governance and management but were anxious about the transformation process from the manual system.

The general impression in this regard is that automation for staff HR functions will come later at some stage, with the digitisation of teaching and learning methods and student-centric services holding the priority presently. It is somewhat strange because most of the modern digitisation software come as all-inclusive packages. However, lack

Stensaker et al., 'Use, updating and integration of ICT in higher education'.

Európai Tükör 2020/4. 
of training and limitation of training facilities for the staff may be one factor which explains such piecemeal implementation, to begin with.

\subsection{Internal marketing of ICT in the organisation}

None of the universities studied acknowledged the existence of a programme intended on the marketing of ICT activities to the teaching or the non-teaching staff that would motivate or encourage them to go wholeheartedly forward and adopt ICT in a big way. In case of the rural university as quoted by one of the faculty:

Technology has not been as important as it would be in other settings; since the class size is small as compared to other universities, there is no need of an intervening technology ... we often bump into each other for a face to face interaction.

The statement reflects that faculties are comfortable using open education resources for research but when it comes to teaching and day to day activities, they prefer the traditional method. It would provide a huge impetus to the success of ICT in higher educational institutions if the staff is sufficiently motivated. Training is important, but not a sufficient condition to ensure the staff is interested and involved with ICT. One would expect the private players to take the lead in this direction. However, the private university studied did not show behaviour in this regard any different from the governmental organisations.

\subsection{Availability of technical support and backup}

The private university $C$ has a beautiful website, possibly to attract and facilitate students. The website has also an AI bot. Student login and other online facilities to faculty and student are also available. It also has boarded the national digital library and facilitates students and faculty to access the academic and scientific resources as well as up-to-date information. Users also find their relevant information in the shortest possible time. The centrally funded universities have institutional repositories where the faculty can access it through the website for free. More and more faculties are getting digitally competent, now especially so after the Covid scene. Only about 5-10 per cent of them are not digitally savvy.

The appearance of the websites and their functionality suggested that these are not just well designed, but are equally well-maintained. This is suggestive of the fact that ICTs have become a vital part of the market branding, lending their institutions a forward-looking image. ${ }^{38}$ That points at the availability of technical support and backup, too. However, the government-funded universities suffer from a lack of willingness of staff to change from the legacy system and thus a limited utilisation of the built-in capacity of infrastructure.

Selwyn, 'The use of computer technology'. 


\subsection{Availability of web-based online services}

Here are several online services like registration for admission, admission application, payment of fees, registration for examinations and examination results to name a few, that the digital-age university is expected to provide to the students. University A, one of the oldest and largest centrally funded public universities has also initiated e-governance in a big way. The student life cycle of examinations has been running for the last 5 years. Students' fees are still not paid online but everything else that a typical controller of examination functions the examination related issues such as hall ticket, results, and so on are facilitated online. The only way to see the results is online. There is a varying degree of e-services provided by other universities. Rural based university $B$ has the technological prowess but is yet to implement these services. University $C$ (private) has automated student registration and admission process as also the examination registration but maintains the conventional system for declaration of results and all finance-related matters like acceptance of fees and payment of scholarships, and so on. The online university has maximum services online.

The majority of the HEIs chosen for the study have Wi-Fi connectivity. This is the basic facility for e-governance since it facilitates cooperation among various departments and administration. E-mails have become a tool for communication for official purpose and are accepted whereas before Covid this was not the case. Until a few months back, automation of these services was a matter of increased efficiency and convenience as also an attempt to reach out students of distant locations seamlessly. In the present Covid and post-Covid era, these services have become more or less essential to minimise human interface and interaction. By and large, the universities in this study, from each of the categories as mentioned, are ready and equipped with the wherewithal to implement these basic measures and bridge the existing gap.

\section{Conclusion and recommendations}

Integration of ICT in HEIs plays a critical role in the sustainability of HEIs and maintaining a competitive advantage in this digital era. The decision-makers of the higher education institutions share the view that e-governance makes the administration more efficient in terms of swiftness, accuracy, integration and staff and student satisfaction. However, they are sceptical about the change process. The study points out that the centrally-funded institutions have the necessary resources but the leadership and governance practices are missing, unlike the private universities where the leadership provide clear directions to the staff. All the participating universities have varied integration of technology. Moreover, piecemeal implementation has been adopted by the institutions failing to cover all admission processes through e-governance. The rural university also lacks the basic facility of online payments. E-governance for reforming the education system needs to be leveraged by HEIs particularly where the enrolment is large, for instance, the central universities.

For the success of e-governance on the institutional point of view, apart from the allocation of adequate funds for infrastructure, a clear strategy to implement e-governance 
is to be put in place. Next, robust software modules and the flexibility of these modules to adapt to educational settings are required. For the success of e-governance, e-literacy of all stakeholders is necessary. The penetration of smartphones along with internet connectivity has provided access to technology but the use for academic purposes is limited. It is thus concluded that barriers to e-governance are technological or institutional and depends on their resources, policies, or traditions. In most cases, the leader of the centre could successfully recognise barriers and find solutions. ${ }^{39}$ Another identified and obvious barrier according to the administrative heads was underprepared human resources. It was suggested through discussions that the faculty members who are fluent with using technology can provide feedback about the current needs of ICT experts and other staff. Moreover, another recommendation is the collaboration of faculty and students within the institution and between institutions. The pooling of resources through digital library and sharing of software can be promoted within institutions.

Through this study, it is learnt that a common e-governance module can be developed for higher education institutions on a cloud platform to smoothen the various backend processes. Proper training to on-board the software is also necessary to help them change to digital transformation. Keeping in view the status of e-governance projects in HEIs, the policymakers and central leaders in higher education should take responsibility for creating conditions that facilitate the transformation process and encourage collaboration among institutions for best practices.

\section{References}

Agarwal, Pawan: Indian Higher Education: Envisioning the Future. New Delhi: Sage Publications, 2009. Online: http://dx.doi.org/10.4135/9788132104094

AISHE Final Report 2018-2019. Online: www.scribd.com/document/436745408/AISHE-Final-Report-2018-19-pdf

Bhushan, Sudhanshu (ed.): The Future of Higher Education in India. Singapore: Springer, 2019. Online: https://doi.org/10.1007/978-981-32-9061-7

Carnoy, Martin - Rafiq Dossani: The Changing Governance of Higher Education in India. Working Paper, Stanford University, 2011.

De Coster, Isabelle et al.: Higher Education Governance in Europe: Policies, Structure, Funding and Academic Staff. Brussels: European Commission, 2008. Online: https://doi. org/10.2766/29900

GoI, Annual Report 2005-2006 of the Ministry of Personnel, Public Grievances and Pensions. New Delhi: Government of India, 2006.

Governance in Higher Education, UGC handbook for Vice-Chancellors. New Delhi: UGC, 2019.

Jahan, K K - D C Selvarani: 'Higher Education in India: Issues and Challenges'. International Conference on Humanities, Literature and Management (ICHLM'15) January 9-10, Dubai (UAE), 2015, 81-86. Online: https://doi.org/10.5958/23215828.2019.00110.4

39 Wang et al., 'Optimal professional development ICT training initiatives'. 
Jameson, Jill: 'E-Leadership in higher education: The fifth "age" of educational technology research'. British Journal of Educational Technology 44, no 6 (2013), 889-915. Online: https://doi.org/10.1111/bjet.12103

Kumar, Jagadesh M: ‘Global University Rankings: What should India do?' IETE Technical Review 32, no 2 (2015), 81-83. Online: https://doi.org/10.1080/02564602.2015.10 26048

Krishnaveni, R - J Meenakumari: 'Usage of ICT for Information Administration in Higher Education Institutions - A Study'. International Journal of Environmental Science and Development 1, no 3 (2010), 282-286. Online: https://doi.org/10.7763/ ijesd.2010.v1.55

Malik, Garima: Governance and Management of Higher Education Institutions in India. New Delhi: NUEPA, 2017.

Mitra, Anuneeta: 'Public Spending in Higher Education in India: A Benefit Incidence Analysis'. Higher Education for the Future 2, no 1 (2015), 71-91. Online: https://doi. org/10.1177/2347631114558191

Muttoo, Sunil K - Rajan Gupta - Saibal Kumar Pal: E-Governance in India. Singapore: Springer, 2019. Online: https://doi.org/10.1007/978-981-13-8852-1

Mukhopadhyay, Marmar - Madhu Parhar: 'ICT in Indian Higher Education Administration and Management', in ICT in Education in Global Context: Lecture Notes in Educational Technology, ed. by Ronghuai Huang, Kinshuk and Jon K Price. BerlinHeidelberg: Springer, 2014. Online: https://doi.org/10.1007/978-3-662-439272_15

Oliver, Ron: 'The role of ICT in higher education for the $21^{\text {st }}$ century: ICT as a change agent for education', January 2002.

Palvia, Shailendra C - Sushil S Sharma: 'E-government and e-governance: Definitions/ domain framework and status around the world', in Foundations of E-government, ed. by Ashok Agarwal and V Venkata Ramana. ICEG 2007, 1-12.

Pegu, Uttam K: 'Information and Communication Technology in Higher Education in India: Challenges and Opportunities'. International Journal of Information and Computation Technology, 4 (2014), 513-518.

Prensky, Marc: 'Digital Natives, Digital Immigrants'. On the Horizon 9, no 5 (2001), 1-6. Online: https://doi.org/10.1108/10748120110424816

Ramganesh, Ekambaram - Ezra Kirubakaran - R Gobi: 'A Roadmap for a Higher Learning Institution-based M-governance Framework in the Grey Revolution'. International Journal of Advanced Research in Computer Science and Software Engineering 5, no 8 (2015), 152-155.

Samuelson, Paul A: 'The Pure Theory of Public Expenditure'. The Review of Economics and Statistics 36, no 4 (1954), 387-389. Online: https://doi.org/10.2307/1925895

Saxena, R P: 'Governance of Indian Universities: From Decay to Dynamism?' Higher Education 20, no 1 (1990), 91-111. Online: https://doi.org/10.1007/bf00162206

Sedwal, Mona: 'The Emergence and Expansion of Indian Universities Before Independence: A Historical Perspective', in The Future of Higher Education in India, ed. by Sudhanshu Bhushan. Singapore: Springer, 2019, 23-40. Online: https://doi. org/10.1007/978-981-32-9061-7_2 
Selwyn, Neil: 'The use of computer technology in university teaching and learning: a critical perspective'. Journal of Computer Assisted Learning 23, no 2 (2007), 83-94. Online: https://doi.org/10.11111/j.1365-2729.2006.00204.x

Stensaker, Bjorn - Peter Maassen - Monika Borgan - Mette Oftebro - Berit Karseth: 'Use, updating and integration of ICT in higher education: Linking purpose, people and pedagogy'. Higher Education 54, no 3 (2007), 417-433. Online: https://doi. org/10.1007/s10734-006-9004-x

UGC: 'Annual Report 2018-2019'. Online: www.ugc.ac.in/pdfnews/3060779_ugcannual-report-english-2018-19.pdf

UN E-Government Survey 2020. Online: https://publicadministration.un.org/egovkb/ en-us/Reports/UN-E-Government-Survey-2020

Wang, Xi - W James Jacob - Christopher C Blakesley - Weiyan Xiong - Huiyuan Ye - Shangmou Xu - Fang Lu: 'Optimal professional development ICT training initiatives at flagship universities'. Education and Information Technologies 25 (2020), 4397-4416. Online: https://doi.org/10.1007/s10639-020-10154-y 